\title{
Analyses of the effectiveness of management of national educational systems by the example of the experience of leading countries
}

\author{
Svetlana Pryadko ${ }^{1 *}$, Boris Tkhorikov ${ }^{1,}$ Alina Vinnik $^{1}$ and Nikolai Dolinsky ${ }^{1}$ \\ ${ }^{1}$ Belgorod State National Research University, 308015, Belgorod, Russia
}

\begin{abstract}
The article presents the results of a study of the effectiveness of management of national educational systems by the example of the North American, European and Scandinavian models of higher education as the most successful in accordance with the data of leading world rankings. The study took place in two stages. At the first stage, the main factors affecting the efficiency and competitiveness of the educational system were ranked, such as: high government spending on the education system, continuous increase in accessibility of higher education for the population, ensuring high quality educational services, export orientation, and others. At the second stage of the study, a system of indicators was formed to evaluate the effectiveness of managing national educational systems, which are presented by the example of the leading countries - representatives of the North American, European and Scandinavian models of higher education (the USA, the UK and Sweden). In addition to quantitative indicators, such as the number of students or government spending on education, which may have a rather large variation of values, since they are related to objective parameters: the total population of a country or occupied territories. We also identified quality indicators: mobility ratios, enrollment in higher education, etc.
\end{abstract}

\section{Introduction}

The urgency of the research problem is due to the increasing importance of the higher education sector in the social and economic development of the leading countries of the world. The system of higher education is a key sector of world trade in services, especially in the countries in which this industry develops as an export.

The study showed that there is an increase in the demand for higher education among the population of the leading countries of the world, while this trend, according to official data of IIASA Global Education Trends (GET), will continue in the coming decades (Figure 1).

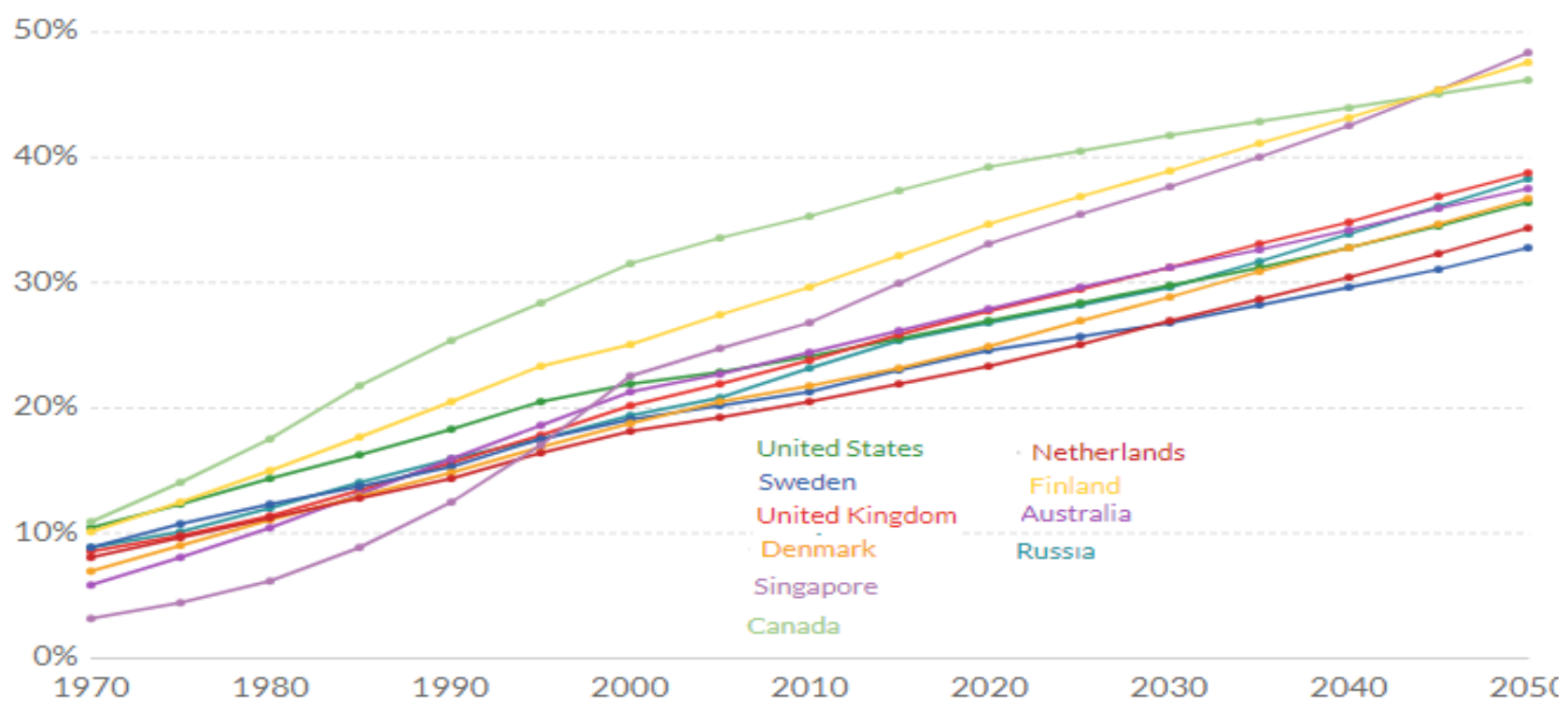

Fig.1. Forecast on the world's leading countries enfolded with higher education [3]

\footnotetext{
* Corresponding author: Pryadko s@bsu.edu.ru
} 
The last two decades have seen a small but general increase in the share of income that countries devote to education. The following chart plots trends in public expenditure on education as a share of GDP (Figure 2).

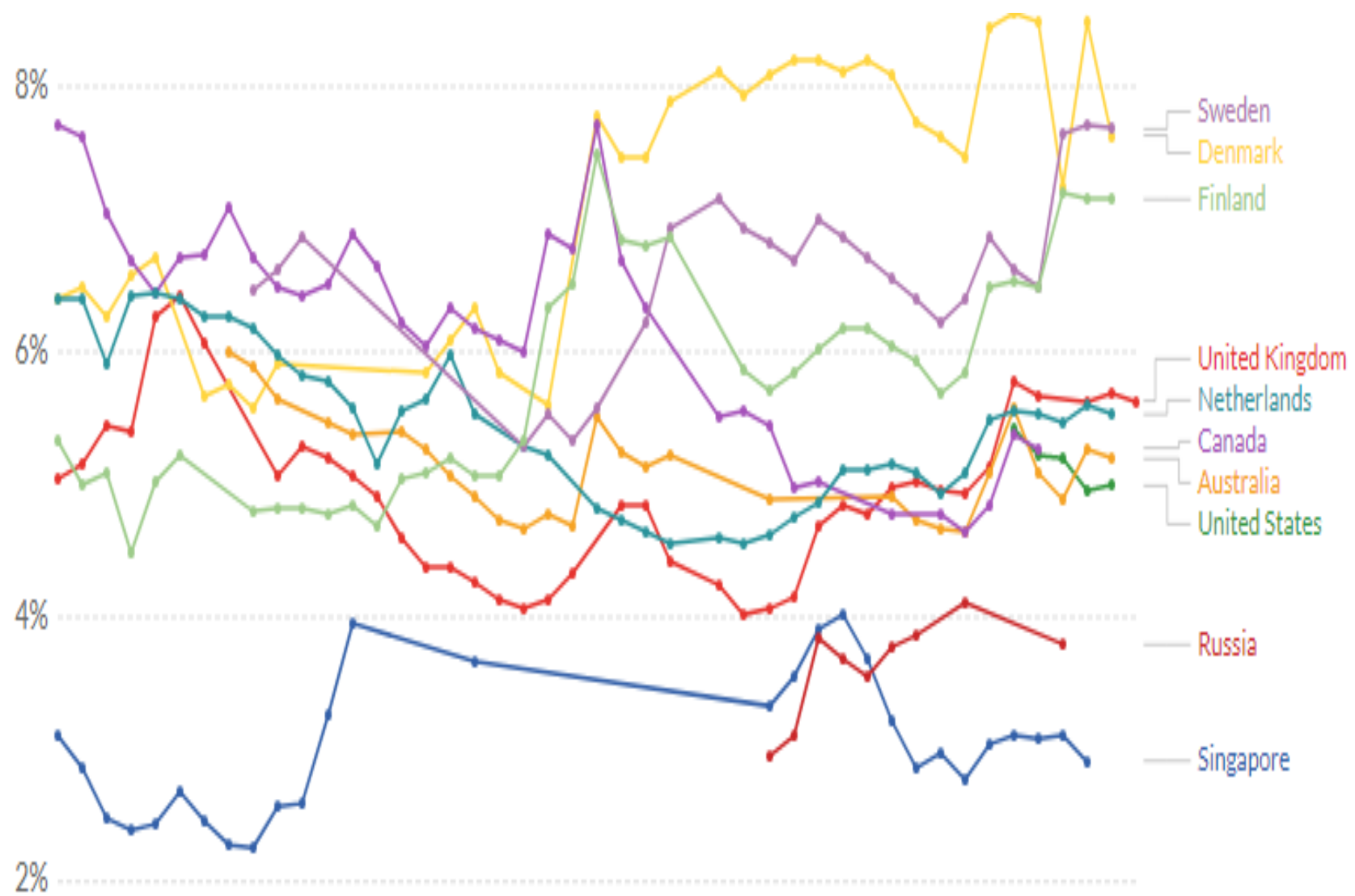

$0 \%$

\section{1} 1980 1990

Fig.2. Total government expenditure on education (\% GDP) [3]

The search for opportunities to improve the efficiency and competitiveness of the Russian higher education sector by the example of leading countries actualizes and enhances the practical significance of the research problem.

\section{Materials and methods}

The logical-structural design of the study included the following steps:

1. Identification of the main factors affecting the efficiency and competitiveness of the higher education system of the leading countries in the global market for educational services. The object of the research was the American, European and Scandinavian systems of higher education, the features of which were examined by the experience of the most successful representatives of these models - the USA, the UK and Sweden.

2. Formation of a system of indicators to evaluate the effectiveness of the management of educational organizations (for example, the objects of study).

\section{Results}

The global market for higher education services was formed after the Second World War under the influence of the most developed national systems, the strongest of which are North American (USA, Canada), European (the United Kingdom), Australian, Scandinavian (Denmark, Sweden), Russian and Southeast Asia systems (Singapore, Japan).

Currently, the higher education system is a key segment of the global market for educational services, the 
potential of which, according to official UNESCO data, is more than 140 million students [2]. Higher schools from over 120 countries offer educational services to applicants; however, the main competition is mainly between leading universities in the North.

America, Western Europe, as well as Australia and Japan have over $4 / 5$ of all foreign students study. The data of the leading international rankings show that the leading positions in the world market of educational services for a long period of time are held by groups of countries - leaders of economic and social development, which is confirmed by the data of the Universities 21 rating, the «top-20» of which for the last five years is presented in [6] (Table 1).

On the basis of the presented data, it can be noted that the leading positions in the global market of educational services are occupied by universities in the USA, the UK, Australia, France, Canada, Sweden and Switzerland. During the study period, Russia in this ranking holds positions in the range of 32-35 places.

An analysis of the management features of the higher education system in leading countries made it possible to single out the main factors influencing their position in the global educational services market, including:

1. high government spending on the education system, in particular on higher education. For example, in Sweden, investment in higher education is higher than in the OECD countries in average $(1.8 \%$ compared with $1.6 \%$ of the country's GDP, respectively). Swedish higher educational system is mainly represented by state universities, which are funded by the country's government by $80 \%$.

2. increasing the accessibility of higher education for the population. An example is the US higher education system. So, there are some state programs that provide consultations and tutoring sessions to prepare students from low-income families to enter the university.
Table 1. Top-20 rankings of national systems of higher education, «Universitas 21»

\begin{tabular}{|c|c|c|c|c|c|c|c|c|c|c|}
\hline & \multicolumn{2}{|c|}{2014} & \multicolumn{2}{|c|}{2015} & \multicolumn{2}{|c|}{2016} & \multicolumn{2}{|c|}{2017} & \multicolumn{2}{|c|}{2018} \\
\hline Country & 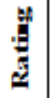 & 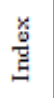 & E & 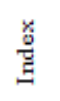 & 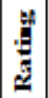 & 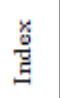 & $\begin{array}{l}y \\
\ddot{y}\end{array}$ & 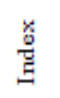 & 㞱 & $\begin{array}{l}\stackrel{x}{\varrho} \\
\stackrel{\Xi}{\Xi}\end{array}$ \\
\hline The USA & 1 & 100 & 1 & 100 & 1 & 100 & 1 & 100 & 1 & 100 \\
\hline Switzerland & 6 & 81.5 & 2 & 87,1 & 2 & 87.2 & 2 & 86.9 & 2 & 88 \\
\hline The UK & 8 & 79.2 & 8 & 80,6 & 4 & 84.8 & 3 & 85.5 & 3 & 82,6 \\
\hline Denmark & 4 & 82.8 & 3 & 85,3 & 3 & 84.2 & 4 & 83.5 & 5 & 81,7 \\
\hline Sweden & 2 & 86.7 & 5 & 84,7 & 5 & 82.2 & 5 & 83.4 & 4 & 82,4 \\
\hline Singapore & 10 & 763 & 9 & 80,3 & 8 & 80.6 & 6 & 80.8 & 9 & 79,5 \\
\hline Canada & 3 & 829 & 6 & 82,8 & 9 & 79.6 & 7 & 80,2 & 8 & 79,6 \\
\hline Netherlands & 7 & 80.4 & 7 & 81,6 & 7 & 81.6 & 8 & 80,0 & 6 & 79,7 \\
\hline Finland & 5 & 82.2 & 4 & 85,2 & 6 & 82.0 & 9 & 79.9 & 6 & 79,7 \\
\hline Australia & 9 & 78.0 & 10 & 77,1 & 10 & 77.6 & 10 & 79,6 & 10 & 78,6 \\
\hline Austria & 12 & 73,7 & 13 & 74,6 & 13 & 74,7 & 11 & 75,0 & 11 & 75.8 \\
\hline Belgium & 13 & 73,1 & 11 & 76 & 11 & 75,7 & 12 & 74,2 & 13 & 73.3 \\
\hline Norway & 11 & 75 & 12 & 75,3 & 12 & 75,3 & 13 & 73,9 & 12 & 74.5 \\
\hline Hong Kong & 15 & 70,6 & 15 & 70,3 & 14 & 70,9 & 14 & 73,7 & 17 & 67.8 \\
\hline New Zealand & 16 & 70,4 & 16 & 69,6 & 15 & 70,9 & 15 & 72,1 & 14 & 71.1 \\
\hline Germany & 14 & 71,1 & 14 & 72,1 & 16 & 70,3 & 16 & 68,8 & 15 & 69.2 \\
\hline Israel & 19 & 68,5 & 19 & 66,4 & 18 & 67,6 & 16 & 68,8 & 18 & 66.3 \\
\hline France & 18 & 68,7 & 17 & 69,3 & 17 & 68,3 & 18 & 67,5 & 16 & 68.5 \\
\hline Ireland & 17 & 69,7 & 18 & 68,8 & 19 & 65,2 & 19 & 66,7 & 19 & 64.8 \\
\hline Japan & 20 & 64,9 & 20 & 65,6 & 20 & 64,2 & 20 & 63,2 & 20 & 61.9 \\
\hline
\end{tabular}

In addition, there is a $20 \%$ tax discount on loans for educational purposes, as well as the possibility of obtaining direct financial assistance in the form of a subsidy returned to students after their employment for 10-15 years [7] (Figure 3).

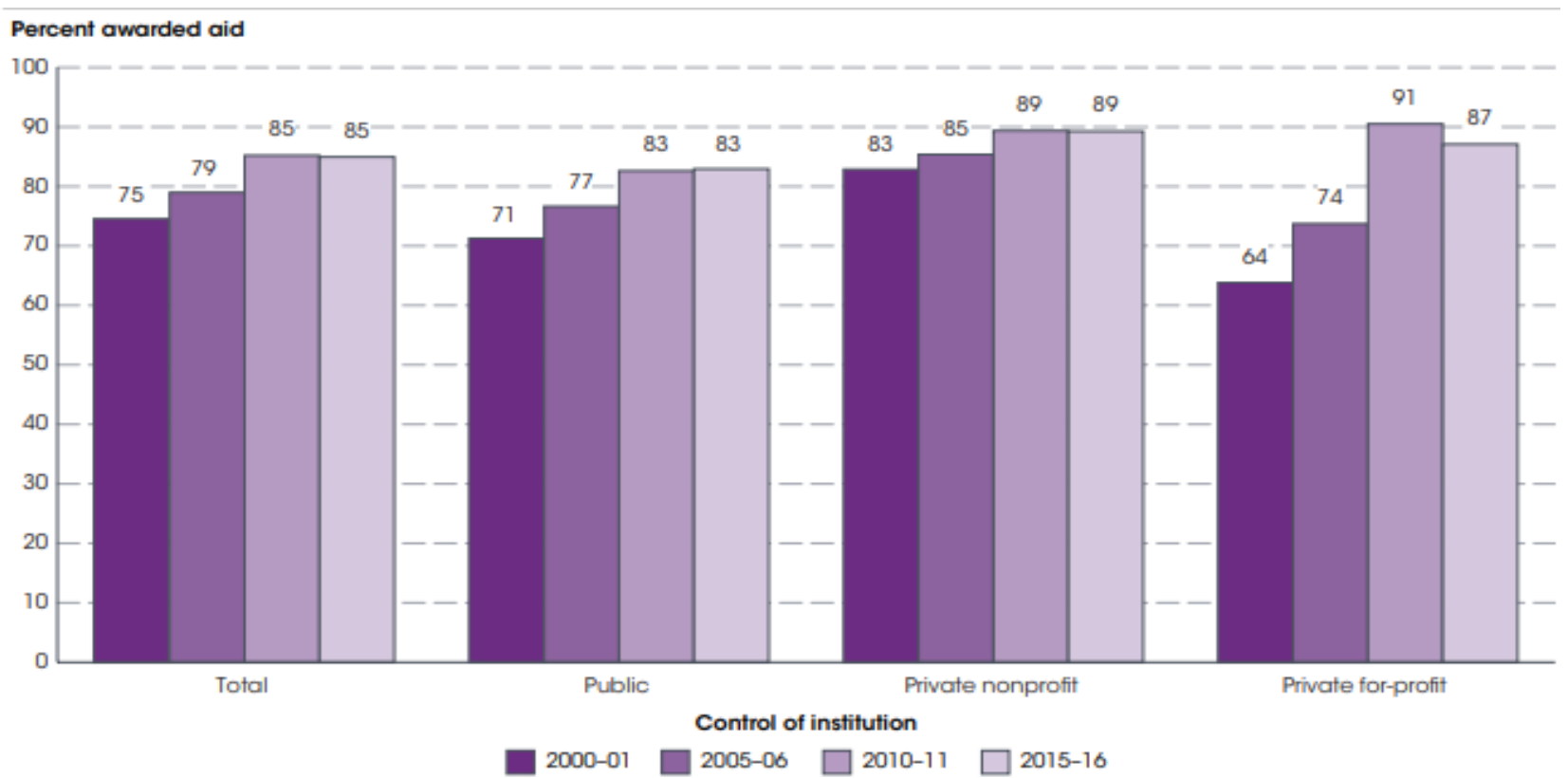

Fig. 3. Percentage of first-time, full-time undergraduate students awarded financial aid at 4-year degree-granting postsecondary institutions, by control of institution: Academic years 2000-01, 2005-06, 2010-11, and 2015-16 [10] 
3. Orientation to the export of educational services and increasing the attractiveness of universities in the world market. For example, one of the leading exporters of educational services in the world market is the United States (Figure 4). As of March 2018, more than a million students from 229 countries studied in the country, most of whom are from Asia, which contributes to replenishing the country's budget by more than $\$ 30$ billion a year [5].

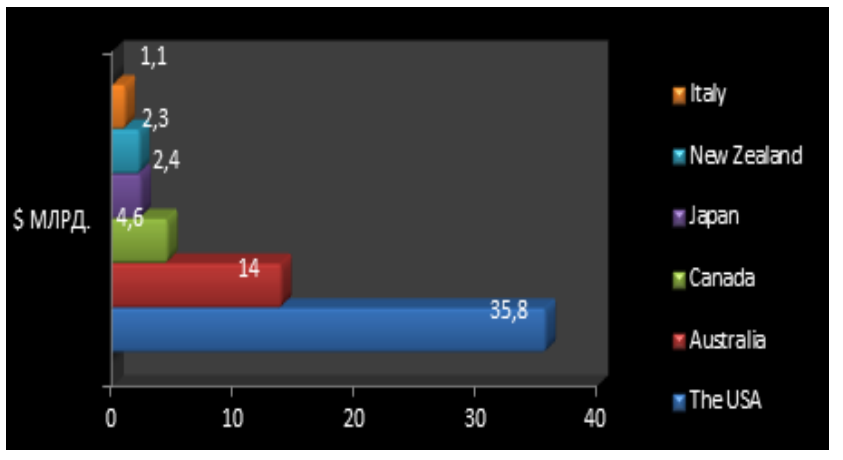

Fig. 4. Leading countries for the export of educational services

4. Attracting private investment to finance the education system and conduct joint research. The UK experience shows that investment in higher education is carried out not only by the state, but also by business. It should be noted that in recent years, joint projects of private business and universities have a priority in state financing, which has contributed to an increase in the number of research personnel of educational organizations, as well as the number of studies conducted for external commercial customers [1]. In Sweden, the state provides financial support for the research activities of universities and university colleges in such priority areas as medicine, technological development and the natural sciences [11].

\section{Discussion}

At the second stage of the study, based on the generalized experience of leading countries, the authors formed a system of indicators to evaluate the effectiveness of the management of educational organizations by the example of the United States, the United Kingdom and Sweden, which are partially presented in Table 2 and Table 3.

Table 2. The system of indicators characterizing the effectiveness of the management of leading educational organizations (by the example of the United States, the UK and Sweden), 2015 [4]

\begin{tabular}{|l|r|r|r|}
\hline \multirow{2}{*}{\multicolumn{1}{|c|}{ Indicator }} & \multicolumn{3}{|c|}{2015} \\
\cline { 2 - 4 } & \multicolumn{1}{|c|}{ The USA } & \multicolumn{1}{c|}{ The UK } & \multicolumn{1}{c|}{ Sweden } \\
\hline $\begin{array}{l}\text { State Higher } \\
\text { Educational Expenses } \\
\text { in \% of GDP }\end{array}$ & 1,37 & 1,29 & 1,94 \\
\hline $\begin{array}{l}\text { State Higher } \\
\text { Educational Expenses } \\
\text { in million dollars }\end{array}$ & 229044,64 & 38847,76 & 11138,59 \\
\hline $\begin{array}{l}\text { Gross enrollment ratio } \\
\text { in higher education, \% }\end{array}$ & 88,9 & 57,3 & 62,3 \\
\hline $\begin{array}{l}\text { Total number of } \\
\text { university students, all } \\
\text { programs }\end{array}$ & 19531727,0 & 2330334,5 & 428557,0 \\
\hline Inbound mobility ratio & 4,65 & 18,58 & 6,22 \\
\hline
\end{tabular}

\begin{tabular}{|l|l|l|l|}
\hline Outbound mobility rate & 1,81 & 1,35 & 4,06 \\
\hline
\end{tabular}

In addition to quantitative indicators, such as the number of students or government spending on education, which may have a rather large variation of values, since they are related to objective parameters: the total population of a country or occupied territories.

We also identified quality indicators: mobility ratios, enrollment in higher education, etc. According to the data presented, it can be seen that the selected countries have approximately the same level of expenditure on higher education and high enrollment rates with higher education (the UK can be considered an exception). Also, the UK has the highest rates of incoming mobility, which indicates the high quality of educational services provided.

Table 3. The system of indicators characterizing the effectiveness of the management of leading educational organizations (by the example of the United States, Britain and Sweden), 2016 [4]

\begin{tabular}{|l|c|c|c|}
\hline \multirow{2}{*}{\multicolumn{1}{|c|}{ Indicator }} & \multicolumn{3}{|c|}{2016} \\
\cline { 2 - 4 } & The USA & $\begin{array}{c}\text { Great } \\
\text { Britain }\end{array}$ & Sweden \\
\hline $\begin{array}{l}\text { State Higher } \\
\text { Educational Expenses } \\
\text { in \% of GDP }\end{array}$ & 1,37 & 1,34 & 1,88 \\
\hline $\begin{array}{l}\text { State Higher } \\
\text { Educational Expenses } \\
\text { in million dollars }\end{array}$ & 239344,46 & 38668,44 & 9367,27 \\
\hline $\begin{array}{l}\text { Gross enrollment ratio } \\
\text { in higher education, \% }\end{array}$ & 88,8 & 59,4 & 63,5 \\
\hline $\begin{array}{l}\text { Total number of } \\
\text { university students, all } \\
\text { programs }\end{array}$ & 19288423,5 & 2387280,2 & 426188,0 \\
\hline Inbound mobility ratio & 5,04 & 18,10 & 6,58 \\
\hline $\begin{array}{l}\text { Outbound mobility } \\
\text { rate }\end{array}$ & 1,84 & 1,42 & 4,05 \\
\hline
\end{tabular}

The effectiveness of the management of the higher education system is also confirmed by the high positions of educational organizations in these countries in leading international rankings, including The Academic Ranking of World Universities (ARWU), QS World University Ranking and The Times Ranking. For example, in Figure 5, the data characterizing the dynamics of representation of educational institutions in the USA, the UK and Sweden in the top 20 and top 100 academic rankings (ARWU) are clearly presented.

\footnotetext{
*Corresponding author: Pryadko s@bsu.edu.ru
} 


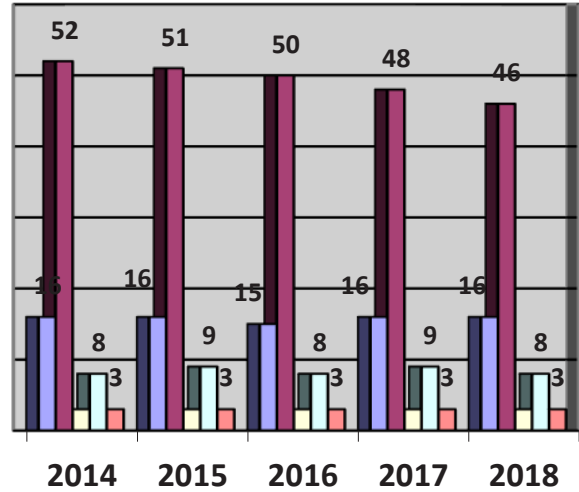

\begin{tabular}{|c|c|c|}
\hline 口The USA Top-20 & 口The USA Top-100 & 口The UK Top-20 \\
\hline 口The UK Top-100 & 口Sweden Top-100 & \\
\hline
\end{tabular}

Fig. 5. Official data on the representation of universities in the analyzed countries in the top 20 and top 100 ARWU [8]

According to the data presented, the leader of the ranking is the United States, which in 2018 were the 46th in the top 100 , and the 16th in the top 20. The UK is in second place (top 100 - 8 universities, top - 20 - 3 universities). Sweden in this ranking includes only the top 100 and is represented by 3 universities.

For example, in Figure 6, the data characterizing the dynamics of representation of educational institutions in the USA, the UK and Sweden in the top 20 and top 100 The Times Higher Education World University Rankings are clearly presented.

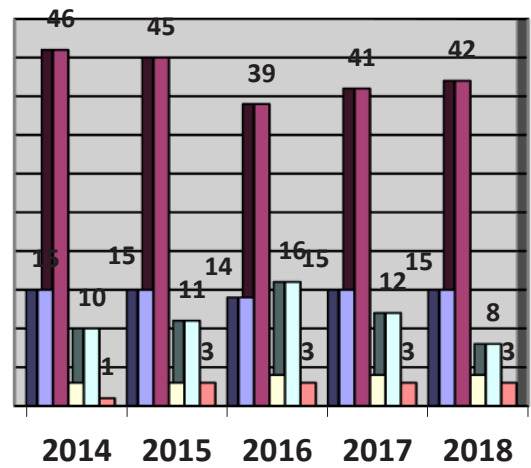

$\begin{array}{lll}\begin{array}{l}\text { 口The USA Top-20 } \\ \text { पThe UK Top-100 }\end{array} & \square \text { The USA Top-100 } & \text { 口The UK Top-20 } \\ \end{array}$

Fig. 6. Official data on the representation of universities in the analyzed countries in the top 20 and top 100 THE [9]

According to the data presented, the leader of the ranking is the United States, which in 2018 were the 42th in the top 100 , and the 15 th in the top 20 . The UK is in second place (top 100 - 11 universities, top - 20 - 4 universities). Sweden in this ranking includes only the top 100 and is represented by 3 universities.

\section{Conclusion}

Thus, the study showed that the higher education system in developed countries plays an important social and economic role and its importance is constantly increasing. Analysis of data describing the effectiveness of managing national educational systems of leading countries showed that several of the most successful can be distinguished: North American, European, Scandinavian, etc.

On the basis of the study of higher education models, we identified the main factors ensuring their effective development: high state the cost of the education system, the constant increase in the availability of higher education for the population, the provision of high quality image services and export orientation, etc. On the basis of the factors that were left out, at the second stage of the study a system of indicators was formed to evaluate the effectiveness of the management of educational organizations, including a number of quantitative and qualitative indicators. The analysis of the selected indicators of the effectiveness of managing national educational systems of countries (United States of Great Britain and Sweden) was also analyzed from the standpoint of data representation in the leading world rankings, such as The Academic Ranking of World Universities (ARWU), QS World University Ranking and The Times Higher Education World University Rankings (THE) and others.

\section{References}

1. O.V. Antonova, Dissertation for the degree of Ph.D. 16 (2012)

2. G.V. Astratova, Journal of Discussion. 9 (72) 17 (2016)

3. M. Roser, E. Ortiz-Ospina, Tertiary Education. Retrieved from: https://ourworldindata.org/ (2019)

4. World data atlas. Retrieved from: https://knoema.ru/atlas (2019)

5. N.A Pavlova, B.V. Nikolaev, E-journal Modern problems of science and education. 6, (2018)

6. Rating of national systems of higher education. Retrieved from: https://universitas21.com/network/u21-openresources-and-publications/u21-rankings/u21-rankingnational-higher-education (2019)

7. I.E. Risin, L.A. Ryzhkova, Modern Economy: Problems and Solutions. 1(1), 25 (2010)

8 . The official website of the academic ranking of universities of the world. Retrieved from: http://www.shanghairanking.com/ARWU2017.html (2019)

9. The official website of the Times Higher Education World University Rankings. Retrieved from: https://gtmarket.ru/ratings/the-world-universityrankings/info.

10. The Condition of Education (U.S. Department of education, 2018) - 384. Retrieved from: https://nces.ed.gov/pubs2018/2018144.pdf (2019).

11. Official website of the Swedish Higher Education Authority. Retrieved from: https://english.uka.se/ (2019) 